\title{
Partial Characterization of Bacteriocins produced by Lactobacillus acidophilus and Pediococcus acidilactici
}

\author{
Nallusamy Sivakumar ${ }^{1 *}$ Rajamani $^{2}$ and Al- Bahry Saif ${ }^{1}$ \\ Department of Biology; College of Science; Sultan Qaboos University; P.O. Box 36; PC 123; Al-Khodh; Muscat- \\ Sultanate of Oman. ${ }^{2}$ Department of Microbiology; J. J. College of Arts and Science; Namanasamudram (PO); \\ Pudukkottai - India
}

\begin{abstract}
Bacteriocin producing Lactobacillus acidophilus and Pediococcus acidilactici were isolated from milk and meat samples, respectively. An attempt was made to produce bacteriocin in a Dairy Based (DB) medium using these organisms. Higher bacteriocin activity was shown by L. acidophilus in the DB medium. Bacteriocins of both the organisms were effective against food pathogens. The bacteriocins were stable at pH 3 - 9 up to 24 hand active at $100^{\circ} \mathrm{C}$. The bacteriocins could be stored at $-20^{\circ} \mathrm{C}$ for at least 45 days, at $4^{\circ} \mathrm{C}$ for 20 days and at $37^{\circ} \mathrm{C}$ for 5 days.
\end{abstract}

Key words: Bacteriocin, Lactobacillus acidophilus, Pediococcus acidilactici

\section{INTRODUCTION}

Bacteriocins are proteinaceous substances produced by many bacterial strains and exhibit bactericidal activity against the closely related organisms. They have been the subject of extensive studies in recent years because of their prospective use as natural food preservatives (Villiani et al., 2001). Lactic acid bacteria (LAB) are widespread in nature and predominate in micro flora of milk and its products. LAB are known to produce bacteriocins and have great potential as food bio-preservatives (Gilliand, 1990; Jamuna and Jeevaratnuam, 2004; Avonts et al., 2004). During fermentation, the lactobacilli metabolize lactose to lactic acid. This lowers $\mathrm{pH}$ and creates an unfavourable environment for pathogens and spoilage organisms (Aslim et al., 2004). In addition to acids, hydrogen peroxide, diacetyl and bacteriocins or bactericidal proteins produced during lactic fermentations may also play inhibitory roles against pathogenic microbes (Lindgren and Dobrogosz, 1990; Zhu et al., 2000). Lactobacillus acidophilus has received more attention and has been the subject of much research because of its ability to produce bacteriocins against other bacteria. Similarly, bacteriocinogenic strains of Pediococcus acidilactici have also been reported (Cintas et al., 1995; Juan C. Neito-Lozano, 2006). The aim of this study was to investigate the growth and bacteriocin production by $L$. acidophilus and $P$. acidilactici in a Dairy Based (DB) medium, their inhibitory effect on food borne pathogens and also the partial characterization of the produced bacteriocin.

*Author for correspondence: apnsiva@yahoo.com 


\section{MATERIALS AND METHODS}

\section{Isolation of Bacteriocin producers}

Bacteriocin producing organisms were isolated from raw milk and raw meat. Samples were diluted and plated on MRS (de Man, Rogosa and Sharpe) medium and bacteriocin activity was assayed by Agar Diffusion Test (ADT) (Yang and Yanling, 1999), using Enterococcus faecalis as an indicator organism because of its sensitivity to all type of bacteriocins. Bacteriocin positive colonies with a large diameter of zone of inhibition were identified according to Bergey's manual of determinative bacteriology (1994) and selected for the further bacteriocin production and characterization studies.

\section{Production of bacteriocin in a DB medium}

Lactic acid fermentation for the production of bacteriocin was accomplished without controlling the $\mathrm{pH}$. Four liters of DB medium (non - fat dry milk $-1 \%$, whey $-2 \%$, yeast extract $-1 \%$, Tween $80-0.2 \%$, manganese sulphate $-0.005 \%$ and magnesium sulphate $-0.005 \%$ ) was sterilized in a 51 bioreactor (Scigenics, India). After cooling the medium, $1 \%$ of a $16-18 \mathrm{~h}$ old Tryptone Glucose Extract (TGE) culture broth of the bacteriocin producer strain was inoculated through the inoculation port of the bioreactor. Fermentation for bacteriocin production was carried out at $37^{\circ} \mathrm{C}$. During fermentation, a small portion of a culture medium was taken from the fermentor through draining port and analyzed for $\mathrm{pH}$, cell growth and bacteriocin activity.

\section{Preparation of bacteriocin}

After fermentation, DB medium with cultures of either $L$. acidophilus or $P$. acidilactici were centrifuged at 5000g (REMI, India) for $15 \mathrm{~min}$. at $4^{\circ} \mathrm{C}$. The supernatants were then filtered through $0.22 \mu \mathrm{m}$ filters (Hi-Media, India) and neutralized to $\mathrm{pH} 6.5$ with $1 \mathrm{~mol} \mathrm{NAOH}$, to eliminate the inhibitory effect caused by the decrease of $\mathrm{pH}$. This was followed by the treatment with catalase to remove the inhibitory action of hydrogen peroxide and dissolved in phosphate buffer at $\mathrm{pH}$ 7.0 at $1 \mathrm{mg} / \mathrm{ml}$ final concentration and incubated for $30 \mathrm{~min}$. at room temperature (Juan C. NeitoLozano, 2006). Supernatants were then concentrated by evaporation and used for further assays. To determine the activity unit (AU) $\mathrm{ml}^{-1}$ of a bacteriocin, $1 \mathrm{ml}$ of the heated culture medium was sequentially diluted with sterile deionised water. Five micro liters from each dilution was placed as spots in the plates seeded with a lawn of bacteriocin sensitive strain. Then the plates were incubated at $30^{\circ} \mathrm{C}$ for 16 to $18 \mathrm{~h}$ and examined for the presence of a clear zone of growth inhibition around the spots. The highest dilution that produced a definite clear circular zone was considered as $1 \mathrm{AU} \mathrm{ml}^{-1}$ (Yang and Yanling, 1999).

\section{Susceptibility of bacteriocin to different enzymes, $\mathrm{pH}$ and temperature}

All characteristic studies were carried out in triplicates and three fold dilution of bacteriocin fractions were taken for all assays. The sensitivity to different enzymes was tested by treating bacteriocin with $1 \mathrm{mg} \mathrm{ml}^{-1}$ of $\alpha$-amylase, protease, lipase and lysozyme for $1 \mathrm{~h}$ at $37^{\circ} \mathrm{C}$ after which the remaining activity was determined by the Agar Diffusion Test (ADT). The effect of $\mathrm{pH}$ was tested by adjusting the $\mathrm{pH}$ in the range of 3-11 using 1 mol $\mathrm{HCl}$ or $1 \mathrm{~mol} \mathrm{NaOH}$ and stored at $4^{\circ} \mathrm{C}$ for 24 h. After storage, $\mathrm{pH}$ values of the tubes were readjusted to 5.5 and the remaining antimicrobial activity of bacteriocin was measured. Aliquots of the crude bacteriocin were subjected to two different heat treatments at 100 and $121^{\circ} \mathrm{C}$ up to $30 \mathrm{~min}$ to evaluate the effect of temperature on the stability of bacteriocin. After heat treatment, the remaining antimicrobial activity of bacteriocin was measured by the ADT method.

\section{Stability of bacteriocin during storage}

Bacteriocin was stored at $4^{\circ} \mathrm{C}$ (refrigerator), $-20^{\circ} \mathrm{C}$ (deep freezer, Blue Star) and $37^{\circ} \mathrm{C}$ for 15 days; at different time intervals, samples were taken from the stored materials for the determination of the remaining activity of bacteriocin.

\section{Interaction of bacteriocin with the sensitive bioassay organism}

To study the interaction of bacteriocin to the sensitive bioassay organism different amount of crude bacteriocin 16, 32, $64 \mathrm{AU} \mathrm{ml}^{-1}$ was added to cultures of the sensitive bioassay strain $E$. faecalis. Bacterial growth was followed by measuring the absorbance at $600 \mathrm{~nm}$. In the control, the sensitive cells were grown without bacteriocin. To study the adsorption of bacteriocin to the sensitive bioassay strain, washed $E$. faecalis cells were suspended in $5 \mathrm{~m} \mathrm{~mol} \mathrm{ml}^{-1}$ sodium phosphate buffer at a cell density of $10^{7} \mathrm{CFU} \mathrm{ml^{-1 }}$. The $\mathrm{pH}$ was adjusted to values between 2.5 and 9 with phosphoric acid (5 


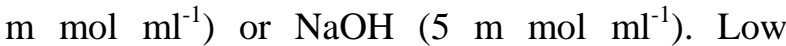
molarity buffer systems were used so that concentrations of phosphate buffer never exceeded $5 \mathrm{~m} \mathrm{~mol} \mathrm{ml}^{-1}$ and did not interfere with the binding of bacteriocin to cells.

\section{RESULTS AND DISCUSSION}

Bacteriocins of lactic acid bacteria have the potential as food bio preservatives to control several pathogenic and spoilage bacteria. For economical and regulatory purposes, these bacteriocins should be produced in large amounts and preferably in a medium composed of foodgrade ingredients. Attempts have been made to produce bacteriocin from different organisms such as Lactobacillus sp., Leuconostoc sp., Lactococcus sp., Pediococcus sp., Streptococcus sp. etc., (Aktypis, 1998; Yang and Yanling, 1999). In this study, an attempt was made to produce bacteriocin in a DB medium and also the partial characterization of bacteriocins produced by $L$. acidophilus and $P$. acidilactici, isolated from milk and meat samples, respectively. Both organisms were tested for their inhibitory activity over some food pathogens such as E. coli, B. cereus, $S$. aureus, S. typhi, V. cholerae, Shigella sp and $E$. faecalis. Almost all the tested pathogens were inhibited by these bacteriocin producers (Table 1). Bacteriocin production was carried out for the $L$. acidophilus and $P$. acidilactici in a fermentor and the samples were drawn at specific intervals of time and analysed for bacteriocin activity, $\mathrm{pH}$ of the production medium and cell growth (Figs. 1and2).

The cell growth of L. acidophilus was higher than $P$. acidilactici in DB medium. Similar results were observed by Yang and Yanling (1999). The low level of multiplication by $P$. acidilactici was due to inability or poor ability to utilize lactose, the principal carbohydrate in DB medium, whereas $L$. acidophilus were lactose fermenters.

Maximum production of bacteriocin was observed after $28 \mathrm{~h}$ of incubation for both $L$. acidophilus and $P$. acidilactici, $L$. acidophilus showed higher bacteriocin activity than the $P$. acidilactici in the DB medium. Yang and Yanling (1999) reported that the higher production of bacteriocin was obtained by Pediococcus sp. than Lactobacillus sp. in the DB medium. This could be due to strain variation and difference in the utilization of lactose. The bacteriocins produced by both organisms were effective against E. faecalis, a sensitive strain to all types of bacteriocin; this result was similar to that of Yang and Yanling (1999) and Oganbanwo (2003).

Table 1 - Inhibition of various food pathogens by bacteriocins of L. acidophilus and P. acidilactici.

\begin{tabular}{lcc}
\hline \multicolumn{2}{c}{ Organism } & \multicolumn{2}{c}{ Inhibition zone (mm) } \\
\cline { 2 - 3 } & L. acidophilus & $\boldsymbol{P}$.acidilactici \\
\hline E. coli MTCC 2939 & ++ & ++ \\
B. cereus MTCC 4079 & + & + \\
S. aureus MTCC 3160 & ++ & ++ \\
S. typhi MTCC3216 & ++ & + \\
V. cholerae MTCC3904 & ++ & + \\
Shigella Sp. & ++ & + \\
E. faecalis MTCC3159 & +++ & ++ \\
\hline
\end{tabular}

Diameter of the inhibition zone: $(+)$ week $(6-9 \mathrm{~mm}),(++)$ intermediate $(10-13 \mathrm{~mm}),(+++)$ strong $(14-16 \mathrm{~mm})$.

The bacteriocin was tested for its sensitivity to various enzymes (Table 2). The antibacterial activity of bacteriocins was entirely eliminated by treatment with protease and amylase, representing a proteinaceous nature and the alleged presence of a glycosidic moiety, which might be required for its activity. Similar observations were made for bacteriocins from other lactic acid bacteria (West and Warner, 1998; Lewus et al., 1991; Jimenez Diaz, 1993; Schved et al., 1993). 


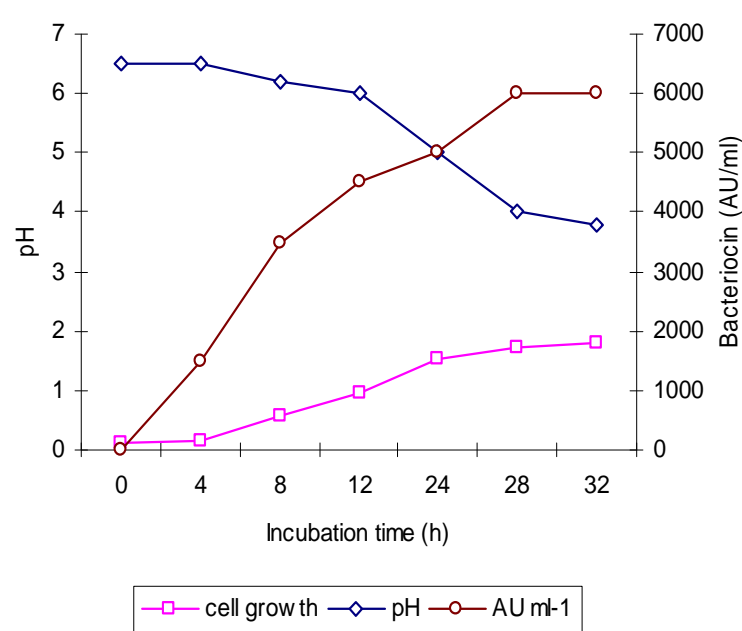

Figure 1 - Production profile of bacteriocin produced by L. acidophilus. (Maximum cellgrowth was $1.8 \mathrm{OD}$ at $600 \mathrm{~nm})$.

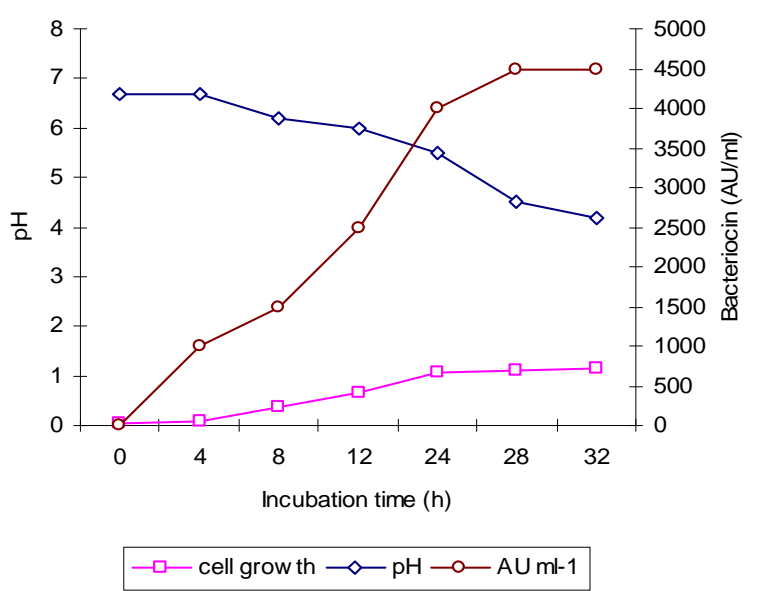

Figure 2 - Production profile of bacteriocin produced by $P$. acidilactici. (Maximum cellgrowth was $1.15 \mathrm{OD}$ at $600 \mathrm{~nm}$ ).

Table 2 - Effect of enzymes on the inhibitory activity of bacteriocins isolated from L. acidophilus and $P$. acidilactici.

\begin{tabular}{|c|c|c|}
\hline Organism & Treatment & Inhibition Zone (mm) \\
\hline \multirow[t]{5}{*}{ L. acidophilus } & None & 6 \\
\hline & $\alpha$-Amylase & - \\
\hline & Protease & - \\
\hline & Lipase & 6 \\
\hline & Lysozyme & 6 \\
\hline \multirow[t]{5}{*}{ P. acidilactici } & None & 4 \\
\hline & $\alpha$-Amylase & - \\
\hline & Protease & - \\
\hline & Lipase & 4 \\
\hline & Lysozyme & 4 \\
\hline
\end{tabular}


The resistance of bacteriocins to wide range of $\mathrm{pH}$ and temperature was also observed in this study. The inhibitory compound produced by the isolates was stable at $\mathrm{pH}$ 3-9 up to $24 \mathrm{~h}$. Some inactivation occurred only at $\mathrm{pH} 10$ and 11 (Table 3).

Bacteriocin from $L$. acidophilus and $P$. acidilactici was subjected to heat treatments at two different temperatures $\left(100\right.$ and $\left.121^{\circ} \mathrm{C}\right)$. After heat treatment, the remaining activity of bacteriocin was determined by the ADT method. The results showed that the crude bacteriocin could be boiled for $30 \mathrm{~min}$ without the loss of activity, but complete inactivation occurred after $10 \mathrm{~min}$ exposure to $121^{\circ} \mathrm{C}$ (Table 4).

Table 3 - Effect of $\mathrm{pH}$ on the inhibitory activity of bacteriocin isolated from L. acidophilus and P. acidilactici.

\begin{tabular}{|c|c|c|c|c|c|c|c|c|c|}
\hline \multirow{3}{*}{ Organism } & \multicolumn{9}{|c|}{$\mathrm{pH}$} \\
\hline & 3 & 4 & 5 & & 7 & 8 & 9 & 10 & 11 \\
\hline & \multicolumn{9}{|c|}{ Inhibition zone (mm) } \\
\hline L. acidophilus & 6 & 6 & 6 & 6 & 6 & 6 & 6 & 5 & 4 \\
\hline P. acidilactici & 4 & 4 & 4 & 4 & 4 & 4 & 4 & 3 & 3 \\
\hline
\end{tabular}

Table 4 - Effect of temperature on the inhibitory activity of bacteriocin isolated from L. acidophilus and P. acidilactici.

\begin{tabular}{ccccc}
\hline \multirow{2}{*}{ Organism } & \multirow{2}{*}{ Treatment } & \multicolumn{3}{c}{ Zone of inhibition (mm) } \\
\cline { 3 - 5 } & & $\mathbf{1 0}$ & Minutes \\
\cline { 3 - 5 } L. acidophilus & $100^{\circ} \mathrm{C}$ & 6 & 6 & $\mathbf{3 0}$ \\
\multirow{3}{*}{ P. acidilactici } & $121^{\circ} \mathrm{C}$ & 6 & - & - \\
& $100^{\circ} \mathrm{C}$ & 4 & 4 & 4 \\
\hline
\end{tabular}

These results were in accordance with Ogunbanwo (2003) who observed that the activity of bacteriocin produced by $L$. brevis remained constant after heating at $121^{\circ} \mathrm{C}$ for $16 \mathrm{~min}$ and at pH 2-8 but declined thereafter. Similarly $L$. plantarum remained constant after heating at $121^{\circ} \mathrm{C}$ for $10 \mathrm{~min}$ and stable at $\mathrm{pH} 2-6$ followed by subsequent decline. According to Aktypis (1998), the resistance of bacteriocin to a wide range of $\mathrm{pH}$ and heat treatment was consistent with the smaller molecular weight of purified bacteriocin. These properties resembled those of Thermophilin A and Thermophilin 347. Effect of time and temperature of storage on bacteriocin activity was also carried out. Bacteriocins from the two organisms were stored at $-20,4$ and $37^{\circ} \mathrm{C}$. Samples were taken from the stored materials at different intervals and the remaining activity was determined. The results indicated that bacteriocin could be stored at $-20^{\circ} \mathrm{C}$ for at least 45 days and at $4^{\circ} \mathrm{C}$ for 20 days. However, during storage at $37^{\circ} \mathrm{C}$, a significant loss of activity occurred from 5 days, probably by the action of proteolytic enzymes which were present in the supernatant fluid (Figs. 3 and 4). This was in accordance with the earlier reports (Aktypis, 1998; Ogunbanwo, 2003).

Bacteriocins showed marked bactericidal action against the sensitive strain E. faecalis, which was concentration dependent (Figs. 5 and 6). Bacteriocin causing lyses of sensitive cells have been reported for several species of lactic acid bacteria (Andersson et al., 1998; Pucci, et al., 1988). However, cell death was not associated with lysis or leakage of the cell membrane was also reported (Ward and Somkuti, 1995; Joerger and Klaenhammer, 1986; Schillinger and Lucke, 1989).

According to Tagg et al. (1976) and Davey (1981), the action of bacteriocin on susceptible cells required an adsorption on the cell envelope receptors of sensitive microorganisms. The adsorption of Thermophilin $\mathrm{T}$ to sensitive cells occurred in the $\mathrm{pH}$ range $2-4$, with the maximum of $75 \%$ at $\mathrm{pH} 2$ (Aktypis, 1998). In the present case, adsorption studies showed that adsorption of bacteriocins to sensitive cells occurred in the $\mathrm{pH}$ range of 3-4 (Fig.7). 


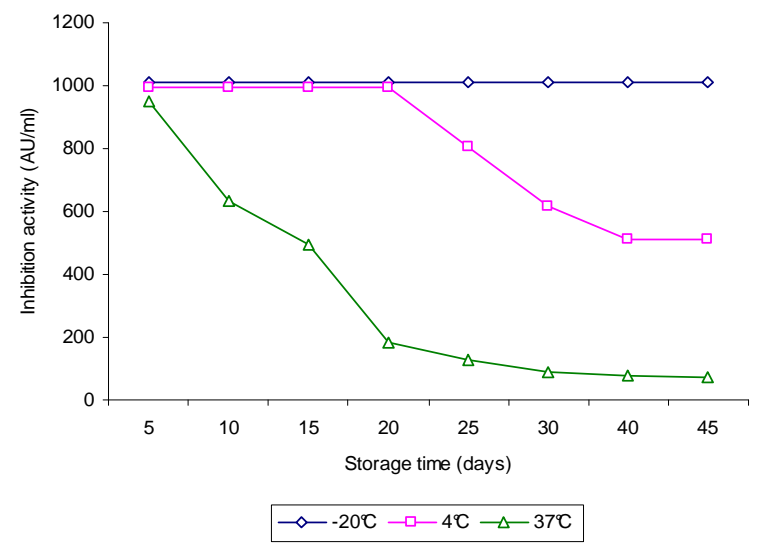

Figure 3 - Effect of storage time and temperature on the inhibitory activity of bacteriocin produced by L. acidophilus.

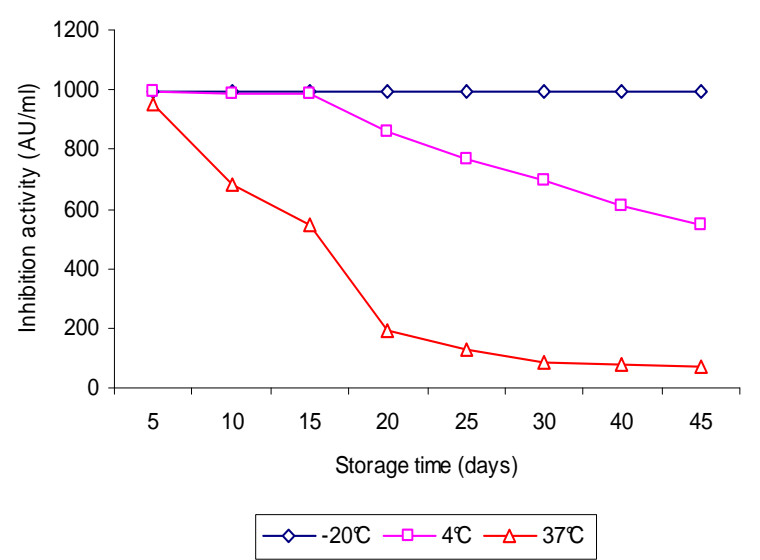

Figure 4 - Effect of storage time and temperature on the inhibitory activity of bacteriocin produced by $P$. acidilactici.

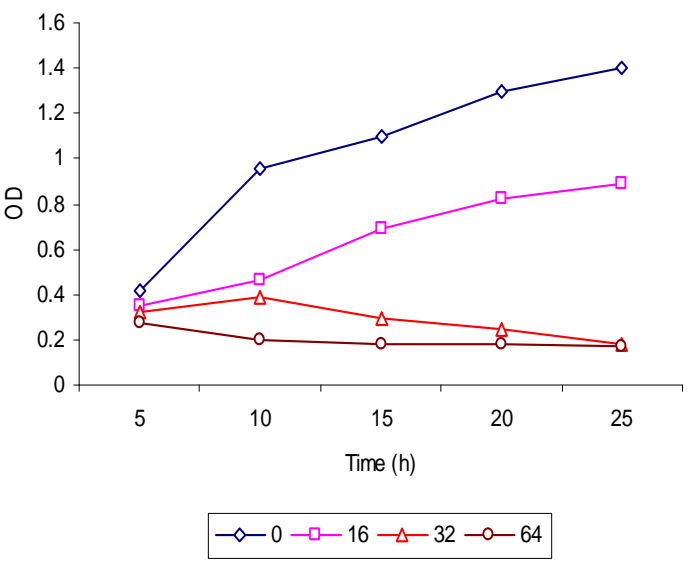

Figure 5 - Effect of different concentrations of bacteriocin $\left(0,16,32\right.$ and $\left.64 \mathrm{AU} \mathrm{ml}^{-1}\right)$ of $L$. acidophilus on the growth of sensitive strain E. faecalis. 


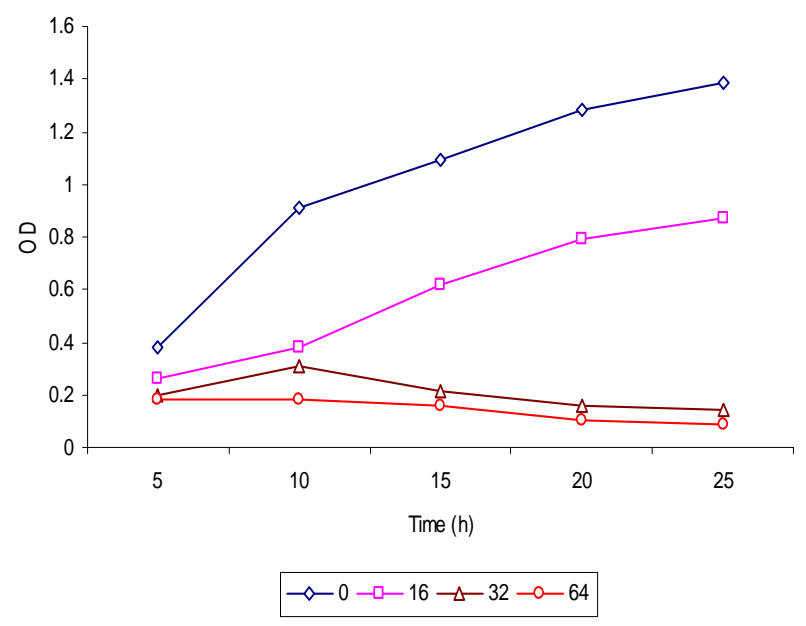

Figure 6 - Effect of different concentrations of bacteriocin $\left(0,16,32\right.$ and $\left.64 \mathrm{AU} \mathrm{ml} l^{-1}\right)$ of $P$. acidilactici on the growth of sensitive strain E. faecalis.

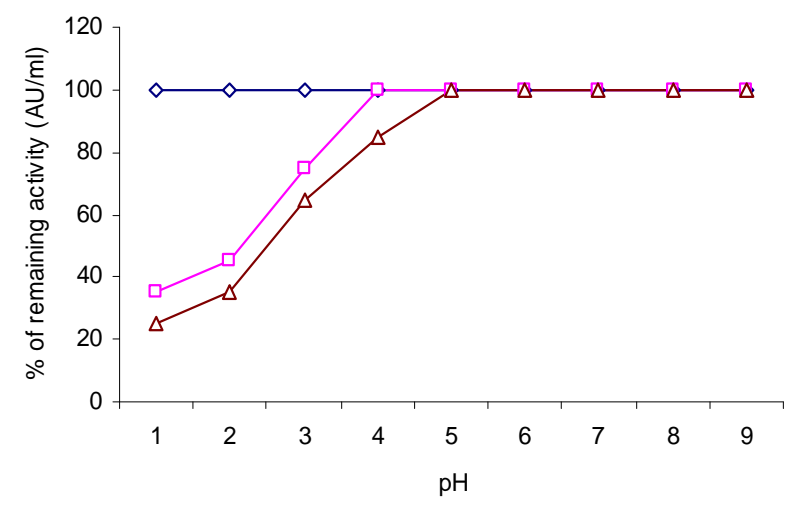

$\checkmark$ Bacteriocin (BA) without cells

$\triangle$ BA of P. acidilactici with sensitive cells

Figure 7 - Effect of $\mathrm{pH}$ on adsorption of bacteriocin to the cells of sensitive strain E. faecalis.

However, inhibitory activity did not require an acidic environment. Bhunia et al., (1991) who studied the mode of action of pediocin $\mathrm{AcH}$ from $P$. acidilactici $\mathrm{H}$ on sensitive cells of $L$. plantarum NCDO 955, observed maximum adsorption at $\mathrm{pH}$ $6.0-6.5$.

Lactobacillus and their by products can be used for several applications. Bacteriocins of Lactobacillus and Pediococcus are inhibitors of food spoilage pathogens. Bacteriocin producers have a survival benefit over the other microbes in the same environment. The isolated strains in this study could have an impact of using as an agent for maintaining hygiene of fermented food materials.

\section{REFERENCES}

Aktypis, A., Kalantzopoulos, G., Ten Brink, B. (1998), Purification and characterization of thermophilin T, a novel bacteriocin produced by Streptococcus thermophilus ACA - DC 0040, Journal of Applied Microbiology, 84, 568 - 576.

Andersson, R.E., Daeschel, M.A., Hassan, H.M. (1998), Antibacterial activity of plantarum SIK - 83, a bacteriocin produced by Lactobacillus plantarum, Biochimie, 70, 381-390. 
Aslim, B., Yuksekdag, Z.N., Sarikaya, E., Beyatli, Y. (2004), Determination of the bacteriocin-like substances produced by some lactic acid bacteria isolated from Turkish dairy products, $L W T$ - Food Science and Technology, 1, 1-4.

Avonts, L.I., Uytven, E.V., De Vuyst, L. (2004), Cell growth and bacteriocin production of probiotic Lactobacillus strains in different media, International Dairy Journal, 14, 947-955.

Bergey, Noel R. Greig. (1994), Bergey's Manual of Determinative Bacteriology, Williams and Wilkins, Philadelphia.

Bhunia, A.K., Ray, B. (1991), Direct detection of an antimicrobial peptide of Pediococcus acidlactici in SDS - polycrylamide gel electrophoresis, Indian Jornal of Microbiology, 2, 319-322.

Cintas, L.M., Rodriguez, J.M., Fernandez, M.F., Sletten, K., Nes, I., Hernandez, P.E. (1995), Isolation and charecterization of pediocin L50, a new bacteriocin from Pediococcus acidilactici with a broad inhibitory spectrum, Applied and Environmental Microbiology, 61, 2643-2648.

Davey, G.P. (1981), Mode of action of diplococcin, a bacteriocin from Streptococcus cremoris, New Zealand Journal of Science and Technology, 16, 187190.

Gilliand, S.E. (1990), Health and nutritional benefits from lactic acid bacteria, FEMS Microbiology Letters, 139, 11 - 23.

Jamuna, M., Jeevaratnuam, K. (2004), Isolation and characterization of Lactobacilli from traditional fermented foods and evaluation of the bacteriocins, Journal of General and Applied Microbiology, 50, 79-90.

Jimenez - Diaz, R., Rios - Sanchez, R.M., Piard, J.C. (1993) Plantaricins $S$ and $T$, two new bacteriocins produced by Lactobacillus plantarum LPC010 isolated from a green olive fermentation, Applied and Environmental Microbiology, 59, 1416-1424.

Joerger, M.C., Klaenhammer, T.R. (1986), Characterization and purification of Helveticin $\mathbf{J}$ and evidence for a chromosomally determined bacteriocin produced by Lactobacillus helveticus, Journal of Bacteriology, 167, 439-446.

Juan C. Neito-Lozano, Juan I. Reguera-Useros, Maria del C.Pelaez-Martinez and Arturo Hardisson de la Torre. (2006), Effect of a bacteriocin produced by Pediococcus acidilactici against Listeria monocytogenes and Clostridium perfringens on Spanish raw meat, Meat Science, 72, 57-61.

Lewus, C.B., Montville, T.J., Banina, A. (1991), Inhibition of food - borne pathogens by bacteriocins from lactic acid bacteria isolated from meat, Applied and Environmental Microbiology, 57, 1683-1688.
Lindgren, S.W., Dobrogosz, W.J. (1990) Antagonistic activities of lactic acid bacteria in food and feed fermentation", FEMS Microbiology Reviews, 87, 149164.

Oganbanwo, S.T., Sanni, A.I., Onilud, A.A. (2003), Characterization of bacteriocin produced by Lactobacillus plantarum $\mathrm{F} 1$ and Lactobacillus brevis OG1, African Journal of Biotechnology, 2, 219-227.

Pucci, M.J., Vedamuthu, E.R., Kinka, B.S., Vanderbergh, P.A. (1988), Inhibition of Listeria monocytogenes by using bacteriocin PA-1 produced by Pediococcus acidilactici, Applied and Environmental Microbiology, 4, 2349-2353.

Schillinger, U., Lucke, F.K. (1989), Antibacterial activity of Lactobacillus sake isolated from meat, Applied and Environmental Microbiology, 55, 19011906.

Schved, F., Lalazar, A., Henis, Y., Junen, J. (1993), Purification, partial characterization and plasmidlinkage of pediocin SJ-1, a bacteriocin produced by Pediococcus acidilactici, Journal of Applied Bacteriology, 74, 67-77.

Tagg, H.G., Dajani, S., Wanamaker, L. (1976), Bacteriocin of Gram positive bacteria, Bacteriology Reviews, 40, 722-756.

Villiani, F., Apone, M., Blaitta, G., Maureillo, G., Pepe, O., Moschetti, G. (2001), Detection and characterization of a bacteriocin, garviencin L-15, produced by Lactococcus garvieae isolated from cows milk, Journal of Applied Microbioogy, 88, 877886.

Ward, D.J., Somkuti, G.A. (1995), Characterization of a bacteriocin produced by Streptococcus thermophilus, Applied Microbiol and Biotechnology, 43, 330-335.

West, C.A., Warner, P.J., Plantacin B, a bacteriocin produced by Lactobacillus plantarum NCD01193, FEMS Microbiology Letters, 49, 163-165.

Yang, A.R., Yanling, M. (1999), Bacteriocin production from lactic acid bacteria in a dairy based medium, Indian Journal of Microbiology, 43, 267-293.

Zhu, W.M., Liu, W., Wu, D.Q. (2000), Isolation and characterization of a new bacteriocin from $L$. gasseri KT7, Journal of Applied Microbiology, 88, 877-886.

Received: January 05, 2009;

Revised: August 11, 2009; Accepted: February 12, 2010. 